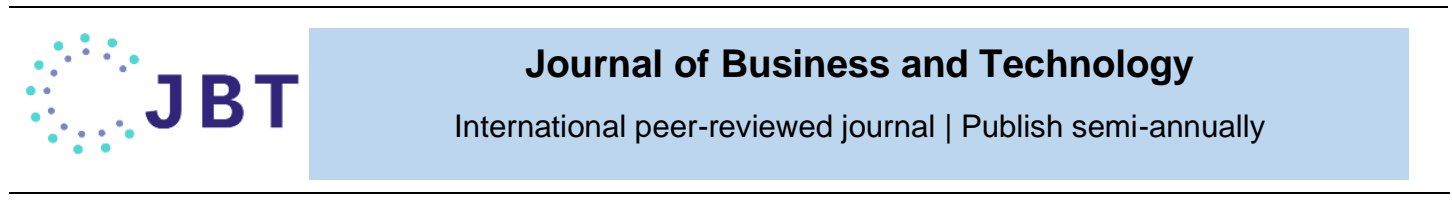

\title{
Impact of brand awareness on customer E-loyalty, in online banking of Sri Lanka: With the mediating effect of emotional attachment with reference to Western province of Sri Lanka
}

\author{
Ferdinando K.P.S.S.M.D.D.S ${ }^{1 *}$ and Yatigammana M.R.K.N ${ }^{2}$ \\ ${ }^{12}$ Department of Commerce and Financial Management, University of Kelaniya, Sri Lanka. \\ * Corresponding Author: dilkishehani2@gmail.com
}

\begin{abstract}
There is a huge need for digital presence in the modern context in businesses. Not only for product based companies but service providing companies such as banks. This is a timely research as banks are moving towards digitalization with the pandemic. Therefore, customer loyalty should be secured when banks provide online banking facilities to customers. The research will be focused on the how brand awareness impacts customer E loyalty when banks provide online banking facilities. In addition, how emotional attachment mediates this impact. Narrowing down the scope to the western province of Sri Lanka, convenience sampling method was adopted to gather data as it adheres with previous literature. Data analysis was done by performing bivariate regression, multiple regression and sobel test to identify the mediating effect. The findings show a significant positive relationship between brand awareness and customer $E$ loyalty and also that there is a mediating effect of emotional attachment. The limitations of the study are the non-generalizability to other industries and the limitedness for the western province in Sri Lanka. The significance of the study is that there a very handful studies done with regard to brand awareness and customer E loyalty in Sri Lanka and it will be very beneficial for brand managers in banks to look into this relationship when providing new online banking facilities and providing a better online service that will enhance brand awareness. Further giving prominence to facilities that creates higher emotional attachment so higher E customer loyalty will be retained.
\end{abstract}

Keywords: Customer E-loyalty, Brand awareness, Emotional Attachment, Online banking, digital banking facilities.

\section{INTRODUCTION}

In a tech driven world, any company needs to have the online presence to conduct businesses in the modern day over traditional presence. A compelling and sociable virtual experience as conceptualized with tele presence and social presence has a significant effect on buying impulses over and above traditional marketing/product stimuli (Shen \& Khalifa, 2012). Not only businesses but also supporting services such as banks digital presence is vital. The financial services environment has been subject to changes on many fronts. Technological change and the advent of the Internet are among the most dramatic and challenging areas of change for the sector
(Bradley \& Stewart, 2003). Not only the development of the technology had led consumers of their financial services lead to moving from traditional banking to online banking, but also the COVID-19 pandemic. Recently a panel discussion was held on the importance of banks going digital and post COVID as well (Jafferjee et al., 2020). Thus, customer loyalty should be secured in terms of online banking as much as it was in traditional banking. Therefore, this is a timely study.

\section{Problem statement}

In existing literature, there were many studies examining various variables in terms of 
consumer aspects and online banking (Dick \& Basu, 1994). When customer loyalty and brand awareness considered, there were studies which stated brand awareness influence or impact customer loyalty (Keller, 1993). There were also, studies where customer loyalty was assessed by several factors (Duy \& Hoang, 2017). Findings of the mentioned article reflected that some variables (price, product quality, service quality) indirectly affected customer loyalty, but brand awareness hypothesis wasn't supported. Therefore, it reflects a theoretical gap. Similarly, there were studies on customer loyalty and emotionality (Levy \& Hino, 2016). Emphasizing that emotional bonds go beyond general service quality, generating strong customer-brand relationships, where some other studies show contradictive results (Garanti \& Kissi, 2019).

According to Duy \& Hoang (2017), customer loyalty in an online environment is compared to traditional physical shops. Results suggest there are two distinct routes influencing customer loyalty in the online shopping process: First a rational way based on comparative analysis of benefits and costs and the second, an emotional way based on better moods and feelings; It creates an unclear grounds as to whether emotionality or emotional attachment has any influence over customer loyalty, or indirectly as a mediator. Hence, the contradiction and doubtfulness of whether brand awareness could affect customer E loyalty, lacks justification to whether emotional attachment affects the two variables. Therefore, it creates a theoretical gap.

Narrowing the scope, as to the western province in Sri Lankan context, handful of studies was done regarding online banking and its effect on customer loyalty. Similar study was carried out of traditional banking concluding a significant relationship between brand awareness and customer loyalty (Jayathilake et al., 2016). Yet it's not in the online environment. Although there are very few researches done with regard to brand awareness and its effect on customer loyalty in Sri Lanka, there was only a very limited research done with regard to brand awareness and its impact on customer loyalty in the online banking context of Sri Lanka, which was identified as the practical gap.

Therefore, this study articulated around Brand awareness and its impact on customer E loyalty in the online banking sector. The objectives of the study were determining the impact of Brand awareness on the customer E loyalty in online banking in Sri Lanka. Secondly, determine the mediating effect of Emotional attachment on the relationship between brand awareness and Customer E loyalty.

\section{LITERATURE REVIEW}

As an approach to the existing literature, with the development of the technology, most companies are moving from traditionalism to digitalization and it often was embraced (Shen \& Khalifa, 2012). In a recent discussion, the importance of moving towards digitalization in the banking sector was discussed (Jafferjee et al., 2020). Therefore, it is important to focus on the Brand awareness and how they can capture the customer's loyalty in a banking digital context, where there's limited studies were done.

\section{Customer E Loyalty}

Customer loyalty is a voluntary user solution for a long time to build relationships with the company. Loyalty is the user's desire for a long time to continue their relationship with a particular company. In the following article, it elaborates customer loyalty couldn't be identified in similar in terms of online or otherwise (Barreda et al., 2013). Studies have defined $\mathrm{E}$ loyalty as a commitment to revisit a brand's website consistently for shopping on that website without switching to other websites .The focus of e-loyalty literature has primarily been to study how e-loyalty can be improved (Cyr et al., 2008). However, since customer loyalty in the digital context was considered, basing on existing literature, the dependent variable of this study was identified as E Customer Loyalty.

\section{Brand Awareness}

Brand awareness has many definitions, but the 
most widely referred definition is as follows. "Awareness refers to the strength of a brands presence in the consumers mind" (Aaker, 1996). To understand the relationship between Customer loyalty and Brand awareness, and as an introduction to Brand awareness to this study, the following articles are explained. Brand equity emerges from two sources namely brand awareness and brand image (Keller, 1993). It explains that the Customerbased brand equity is reflected, when the customer is familiar with the brand and holds some favorable, strong, and unique brand associations in the customers head or memory. This explains both brand awareness and brand image contributes to customer loyalty, but as explained earlier there are contradictions with the results of other studies. There were studies which reflected the idea that brand awareness doesn't impact customer loyalty. Therefore this study wouldn't focus on brand image impact towards customer loyalty as it was previously tested in existing literature, but brand awareness impact on customer E loyalty.

\section{Emotional attachment}

A recent research was done where emotionality is taken as an independent variable and customer loyalty as the dependent variable. The findings show a significant, direct and positive relationship between the customer's emotional attachment and bank loyalty (Levy \& Hino, 2016). The study distinguishes between two integrated pathways consumers possibly follow when making decisions about services: Therefore this research clearly states that emotional attachment and loyalty has a direct positive relationship. Yet, in another study, there were four online personality traits (activity, simplicity, emotionality and aggressiveness) and the findings of that research made it clear that those variables form positive brand equity which ultimately affects customer loyalty, but in contrast, that emotionality and simplicity do not contribute to it (Garanti \& Kissi, 2019). There were another research that supported emotionality (Keller, 1993) to have some effect on customer loyalty, which creates an doubtfulness. Therefore the existing theoretical gap will be eliminated with the present study. The conceptual framework was generated with the previous literature.

\section{Conceptual Framework and Hypotheses}

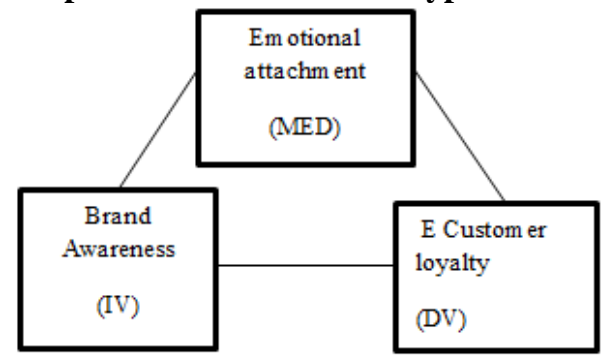

Figure 1: Conceptual Framework and Hypotheses

As per the figure 1, this study focused on how brand awareness will impact customer E loyalty, which was considered as the dependent variable. Looking into how customer E loyalty and brand awareness is connected, the following study confirms the variables behavior as follows (Barreda et al., 2013). Brand awareness positively affects brand image, which implies that the fostering awareness through online social networks (OSN) can improve brand image. Which ultimately results in triggering users' emotional attachment, and higher awareness level and positive image can encourage OSN users to be more loyal. Where in other terms say brand awareness impacts customer loyalty. Discussing this matter in the digital platform, whether brand awareness, emotional appeal and loyalty is connected, this following research could be referred (Barreda et al., 2013).

The mentioned study had developed an ELoyalty model that is discussed during the study. Further, results indicate that brand awareness positively affects brand image. Brand awareness directly and indirectly influences brand emotional attachment and brand evaluations. It had further developed the emotionality into brand emotional attachment. It further explains that higher awareness level and positive image encourage online social network users to be more loyal towards the company. With these results, sufficient 
literature was found to formulate the first hypothesis.

H1: There is a positive impact of Brand awareness on E Customer loyalty in the online banking sector in Sri Lanka.

Existing literature reflected that emotional attachment may result in a direct effect on customer loyalty, yet in this specific research its objective drives towards the researching of the existing knowledge of whether emotional attachment could be a mediator between brand awareness and customer loyalty, as some studies have shown that emotional attachment could be mediating.

The following study outlines how emotional brand attachment is a mediating regarding social media explains social media via shaping consumer perceptions of brand credibility and consumer satisfaction, and the outcome clearly states that a fully mediated effect of emotional brand attachment on social media brand equity is found (Dwivedi et al., 2019). These variables are subdivided into indicators to measure the respective variables and concepts. However (Cyr et al., 2008), in this particular research, Brand awareness and emotionality would be considered as two variables, where Brand awareness will be tested in terms of how it impacts Customer E Loyalty and whether emotionality or emotional attachment would mediate this impact. With that the second hypothesis is derived.

H2: There is a mediating effect of emotional attachment between E customer loyalty and brand awareness.

Further, in a similar research done in the banking sector focusing on customer loyalty and brand awareness, suggests that there is a significant relationship between brand awareness and customer loyalty (Jayathilake et al., 2016) , but this particular research isn't done in terms of online banking but in the traditional banking which justifies the originality of the present study. Concluding, this study was carried out to examine the contradictive results that were identified in the existing to overcome the theoretical gap, also to mitigate the practical gap that was discussed earlier.

\section{RESEARCH METHODOLOGY}

\section{Research Design}

Research philosophy is an important area in the research methodology section. The present study was an Empirical research. Out of positivism and pragmatism, the major philosophies, this research will fall into positivism, as the tradition of working with existing knowledge and theories to develop hypotheses. This study is a quantitative research as many of the basing related articles have used quantitative researches, and it is hoped to carry out in the deductive approach. In that case both Primary and secondary data is used to derive the results (Levy \& Hino, 2016).

\section{Data Collection Method}

The collection of data is done both in Primary and secondary forms. As the secondary form, journal articles from emerald insights were given priority as the articles and studies included there are high in reliability and as the primary data collection, a survey was distributed among the online banking users in the western province. Population of this research is online banking users in Sri Lanka in the western province because computer literacy and the usage of internet in the western province is higher than other provinces according to recent computer literacy statistics. Convenience sampling method via a Google form was adopted as there are practical issues when identifying the whole population. This method complies with previous literature (Suhartanto et al., 2020), further, five point likert scale questionnaire was built aligning the previous literature. Data analysis procedure was carried out with SPSS software. Along with descriptive statistics, Pearson correlation and regression analysis was used to test the hypotheses derived using the conceptual model and to measure the impact of IV on DV. The Cronbach's alpha indicates how well the items in a set are positively correlated to one another and if it is more than 0.7, the measurements of the questionnaire are considered good (Nunnally, 1967). As per the Table 1, the 
results of the pilot test of 30 respondents are meeting Cronbach's alpha requirements (Cronbach alpha value for the three variables $>0.7)$.

\section{Table 1: Reliability and Validity Test of pilot test}

\begin{tabular}{|c|c|c|c|}
\hline Variable & $\begin{array}{l}\text { Cronb } \\
\text { ach's } \\
\text { Alpha }\end{array}$ & $\begin{array}{l}\text { Cronbach's } \\
\text { Alpha } \\
\text { Based on } \\
\text { Standardiz } \\
\text { ed Items }\end{array}$ & $\begin{array}{l}\mathrm{N} \text { of } \\
\text { Items }\end{array}$ \\
\hline $\begin{array}{l}\text { Customer } \\
\text { E loyalty }\end{array}$ & .795 & .803 & 5 \\
\hline $\begin{array}{l}\text { Brand } \\
\text { awareness }\end{array}$ & .719 & .724 & 4 \\
\hline $\begin{array}{l}\text { Emotional } \\
\text { attachment }\end{array}$ & .928 & .930 & 6 \\
\hline
\end{tabular}

\section{FINDINGS AND DISCUSSIONS}

As per Table 2, the Cronbach's alpha is above 0.7 in all three variables, which adheres to guidelines and recommendations set forth by individuals such as (Nunnally, 1967). A composite reliability of 0.6 and an AVE of 0.5 are expected by previous studies (Fornell \& Larcker, 1981), As above, there is a strong relationship creating sufficient convergent validity. Discriminant validity is demonstrated by evidence that measures of constructs that theoretically should not be highly related to each other are, in fact, not found to be highly correlated to each other.

Table 2: Reliability and Validity Test

\begin{tabular}{|c|c|c|c|}
\hline Variable & $\begin{array}{l}\text { Cronbac } \\
\text { h's Alpha }\end{array}$ & CR & AVE \\
\hline $\begin{array}{l}\text { Customer E } \\
\text { Loyalty }\end{array}$ & .795 & .865 & .563 \\
\hline $\begin{array}{l}\text { Emotional } \\
\text { attachment }\end{array}$ & .928 & .946 & .744 \\
\hline $\begin{array}{l}\text { Brand } \\
\text { awareness }\end{array}$ & .719 & .829 & .549 \\
\hline
\end{tabular}

By the use of simple linear regression method, $47.5 \%$ of the variance (which is denoted by $\mathrm{R}$ square) of the Customer E loyalty (DV) was explained by the Brand awareness (IV). It is accepted that the variance percentage is better when it's higher. On the other hand $52.5 \%$ of the variance was explained by other variables which were not taken into consideration in this study.

ANOVA results indicated the significance of the study. The model significance of this research and the $p$ value should be less than 0.5 and in this scenario it is clear that it is 0.000 which then was concluded as this model is statistically significant.

\section{Bivariate Regression Analysis}

Table 3: Coefficient

\begin{tabular}{|lll|}
\hline & $\beta$ & Sig. \\
\hline Brand awareness & .689 & .000 \\
\hline
\end{tabular}

Table 3 denotes the variance of the Independent variable towards the dependent variable. The $R$ represents the simple correlation and its 0.689 which indicates a high degree of correlation, concluding, brand awareness has a positive impact on the Customer E loyalty as it has positive values. Pvalue was less than 0.5 which $(0.000)$ states model is significant. Therefor it is justified that the first hypothesis is accepted rejecting the null hypothesis adhering to previous studies (Jayathilake et al., 2016).

H1: Brand awareness positively impact customer E loyalty-accepted

\section{Regression Analysis}

Regression analysis was carried out to test the second hypothesis. The paths were identified as figure 2 adhering to Sobel Product of Coefficients Approach.

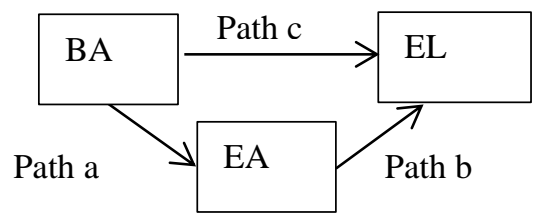

\section{Figure 2}

An equivalent approach calculates the indirect effect by multiplying two regression 
coefficients (Sobel, 1982).

Model 1: $Y=B O+B 1 X+B 2 M+e$

Model 2: $M=B O+B X+e$

\section{Model 1- Multiple regression analysis}

Multiple regressions was used to find the indirect effects of path $c$ and $b$, Brand awareness and emotional attachment acting as the independent variables and customer $\mathrm{E}$ loyalty as the dependent variable. It is statistically significant

Table 4: Coefficients

\begin{tabular}{|l|l|l|l|l|}
\hline & \multicolumn{2}{|l|}{$\begin{array}{l}\text { Unstd. } \\
\text { Coefficient }\end{array}$} & $\beta$ & Sig. \\
\cline { 2 - 4 } & B & $\begin{array}{l}\text { Std. } \\
\text { error }\end{array}$ & & \\
\hline $\begin{array}{l}\text { Brand } \\
\text { awareness }\end{array}$ & .474 & .080 & .504 & .000 \\
\hline $\begin{array}{l}\text { Emotional } \\
\text { attachment }\end{array}$ & .228 & .065 & .300 & .001 \\
\hline
\end{tabular}

a. Dependent Variable: Customer E Loyalty

The Table 4 suggests the path $\mathrm{c}$ beta value is 0.474 and standard error to be 0.080 . Likewise, Path $\mathrm{b}$ beta value as 0.228 and standard error as 0.065 and the model was statistically significant as the $\mathrm{p}$ value $<0.5$

\section{Model 2- Bivariate regression analysis}

The unstandardized Beta value is 0.648 and it is statistically significant as the $\mathrm{p}$ value is $<.05$. The standardized beta value is 0.689 . Since this measure was statistically significant the analysis was continued to find the direct effect of Brand awareness and emotional attachment by bivariate regression. Therefore, values for path A is $0.765(0.094)$ which is considered the direct effect as per the Table 5. Unstandardized beta is 0.765 and this Also, the above values are statistically significant as $\mathrm{p}$ value $<0.5$ and $\beta$ is 0.618

\section{Sobel Test}

Statistics are checked via the Sobel test to identify the mediating effect (Sobel, 1982). Formulae for the tests provided here were drawn from MacKinnon \& Dwyer (Mackinnon \& Dwyer, 1993).

\section{Table 5: Coefficients}

\begin{tabular}{|l|l|l|l|l|}
\hline & \multicolumn{2}{|l|}{$\begin{array}{l}\text { Unstd. } \\
\text { Coefficient }\end{array}$} & $\beta$ & Sig. \\
\cline { 2 - 3 } & B & $\begin{array}{l}\text { Std. } \\
\text { Error }\end{array}$ & \\
\hline $\begin{array}{l}\text { Brand } \\
\text { awareness }\end{array}$ & .765 & .094 & .618 & .000 \\
\hline
\end{tabular}

a. Dependent Variable: Emotional attachment

\section{Table 6: Mediating effect}

\begin{tabular}{|c|c|c|}
\hline \multirow[b]{2}{*}{ Inputs } & \multicolumn{2}{|c|}{$\begin{array}{l}\text { Unstandardized } \\
\text { Coefficients }\end{array}$} \\
\hline & $\mathrm{B}$ & Std. Error \\
\hline Brand awareness & .765 & .094 \\
\hline $\begin{array}{l}\text { Emotional } \\
\text { attachment }\end{array}$ & .474 & .080 \\
\hline
\end{tabular}

As per the results of Sobel test is associated with the $\mathrm{Z}$ value of 4.790 , a standard error of 0.075 and a $p$ value of less than 0.5. So the indirect effect between Brand awareness and customer E loyalty via the intermediary variable of Emotional attachment is statistically significant. This was justified with (Aroian, 1947) and in (Goodman, 1960) as well. Indirect effect was calculated as, (Path a *Path b), thus $0.765 * 0.228=0.17442$. Therefore, 0.17442 is the estimated indirect effect between brand awareness and customer E loyalty through emotional attachment and the Sobel test suggests that value is statistically significant. Therefore, the second hypothesis can be accepted concluding that Brand awareness is mediated by emotional attachment on customer E loyalty adhering to previous studies.

Table 7: Sobel test

\begin{tabular}{|llll|}
\hline & Test statistics & Std. Error & $p$-value \\
\hline Sobel test & 4.79001426 & 0.075701 & 0.00000167 \\
\hline Aroin test & 4.76655379 & 0.076074 & 0.00000187 \\
\hline Goodman test & 4.81382459 & 0.075327 & 0.00000148 \\
\hline
\end{tabular}




\section{CONCLUSIONS AND FUTURE RESEARCH DIRECTIONS}

As brand awareness has a significant positive relationship with customer $\mathrm{E}$ loyalty, it is recommended that banks in Sri Lanka pay more attention to have better brand awareness strategies in terms of digital facilities they provide for online banking needs. With the current Covid-19 pandemic everyone is hoping to execute their tasks from in the comfort of their homes. This had lead many people to use online banking to get their banking needs without visiting outlets. So to maintain and customer base of any bank, it is very important that brand managers of look in to this aspect. Since the results of this study claims when there is higher brand awareness that there is higher customer E loyalty, it is important that upper management of banks in Sri Lanka pay more attention to the Brand awareness when developing online banking facilities

Next, the study justified that emotional attachment mediates the brand awareness on customer E loyalty. This signifies the importance of paying required attention for the emotional attachment the customers have in the online context. When the customers emotionally attached to the brand awareness it was justified that the customer E loyalty positively mediates. This need to be taken in to consideration when the banks are launching loyalty programs for online users to provide benefits to the frequent users. As customer E loyalty is different as it is about the online platform of banking facilities. Therefore, the facilities banks provide should signify that the bank is looking after customers banking needs. Prioritizing online banking facilities according to the demographic factors such as age and income level will lead to higher level of emotional attachment as the banks provides exactly of what the customer needs according to their character based by the demographics.

Therefore, the aim of banks in Sri Lanka should be to develop a better brand awareness that impressive, unique and suited to the target market. Hence, there would be a better emotional attachment of customers with the bank, ultimately enabling the retention and expansion of the loyal customer base in the online context.

The study was limited to the western province of Sri Lanka due to the prevailing situation with the pandemic. Therefore, it is recommended to undertake the similar study in all other provinces including the western province to have a better understanding of how Brand awareness is impacting customer E loyalty with the mediating effect of emotional attachment. Another limitation of the study was, only brand awareness was considered that impacts customer E loyalty and for future studies, similar studies could be carried out with more variables that impacts customer E loyalty. Further, emotional attachment was considered as the mediating factor and future researches may evaluate the effect of other mediating factors that enhances customer $\mathrm{E}$ loyalty in Sri Lanka.

\section{REFERENCES}

Aaker, D. A. (1996). Building strong brands (Vol. 38). New York: Free Press.

Aroian, L. A. (1947). The probability function of the product of two normally distributed variables. Annals of Mathematical Statistics, Vol. 18 No. 2, pp.265-271.

Barreda, A., Nusair, K., Okumus, F., \& Bilgihan, A. (2013). Developing a brand structure pyramid model for travel-related online social networks. Tourism Review, Vol. 68 No. 4, pp.49-70.

Bradley, L., \& Stewart, K. (2003). The Diffusion of Online Banking. Journal of Marketing Management, Vol. 19 No. 9/10, pp. 1087-1109.

Cyr, D., Kindra, G. S., \& Dash, S. (2008). Web site design, trust,satisfaction and eloyalty:the Indian experience . Online Information Review, Vol. 32 No. 6, pp. 773-790.

Dick, A., \& Basu, K. (1994). Customer loyalty: Toward an integrated conceptual framework. Journal of the Academy of 
Marketing Science, Vol. 22 No. 2, pp. 99113.

Duy, P. N., \& Hoang, T. M. (2017). Factors Affecting Customer Satisfaction and Customer Loyalty The Case of Binh Duong Ceramic Product. NIDA International Business Conference, (pp. 380-405). Thailand.

Dwivedi, A., Johnson, L. W., Wilkie, D. C., \& Araujo-Gil, L. D. (2019). Consumer emotional brand attachment with social media brands and social media brand equity. European Journal of Marketing, Vol. 53 No. 6, pp. 1176-1204.

Fornell, C., \& Larcker, D. F. (1981). Evaluating Structural Equation Models with Unobservable Variables and Measurement Error. Journal of Marketing Research, Vol. 18, No. 1, pp. 39-50.

Garanti, Z., \& Kissi, P. S. (2019). The effects of social media brand personality on brand loyalty in the Latvian banking industry: The mediating role of brand equity. International Journal of Bank Marketing, Vol. 37 No. 6, pp. 1480-1503.

Goodman, L. A. (1960). On the Exact Variance of Products. Journal of the American Statistical Association, Vol. 55, No. 292, pp. 708-713.

Jafferjee, M., Fernando, Y., Jayesinghe, M., Abeygoonewardena, R., \& Alles, J. (2020). Advocata panel discusses way forward with Banking Sector Leaders. Advocata . Colombo: Ceylon Today.

Jayathilake, N., Abeysekera, N., Samarasinghe, D., \& LakshanUkkwatte, J. (2016). Factors Affecting For Customer Loyalty In Sri Lankan Banking Sector. International Journal of Marketing and Technology, Vol 6(4), pp. 148-167.

Keller, K. L. (1993). Conceptualizing, Measuring, and Managing Customer-
Based Brand Equity. Journal of Marketing, Vol. 57, No. 1, pp. 1-22.

Levy, S., \& Hino, H. (2016). Emotional brand attachment: a factor in customer-bank relationships. International Journal of Bank Marketing, Vol. 34 No. 2, pp. 136150.

Mackinnon, D. P., \& Dwyer, J. H. (1993). Estimating Mediated Effects in Prevention Studies. Evaluation Review, Vol. 17 No 2, pp. 144-158.

Nunnally, J. C. (1967). Psychometric Theory. New York: McGraw-Hill.

Shen, K. N., \& Khalifa, M. (2012). System design effects on online impulse buying. Internet Research, Vol. 22 No. 4, pp. 396425.

Sobel, M. E. (1982). Asymptotic Confidence Intervals for Indirect Effects in Structural Equation Models. Sociological Methodology, Vol. 13, pp. 290-312 .

Suhartanto, D., Gan, C., Sarah, I. S., \& Setiawan, S. (2020). Loyalty towards Islamic banking:service quality, emotional or religious driven? Journal of Islamic Marketing, Vol. 11 No. 1, pp. 66-80. 